\title{
Conditional alleles, inteins and degrons
}

To the editor:

In a Letter in the July issue (Nat. Biotechnol. 22, 871-876, 2004), Martin Zeidler et al.

describe a new approach for generating

temperature-sensitive alleles based on

conditionally active inteins. The system

described is undoubtedly a novel and

valuable alternative to 'classical' temperature-

sensitive alleles. The authors of the Letter, as

well as Francine Perler in an accompanying

News and Views article (Nat. Biotechnol.

$22,824-826,2004)$, discuss in detail the

advantages of the intein-based system

over classical temperature-sensitive alleles.

However, both Zeidler et al. and Perler

neglect to mention that one alternative to

the classical temperature-sensitive allele has

already been described and successfully used.

This approach is based on the use of a

'heat-inducible degron' cassette that is fused to the protein of interest and causes degradation of the degron together with the fused protein upon the temperature shift ${ }^{1}$. It has been successfully used in both budding ${ }^{2}$ and fission yeasts ${ }^{3,4}$, and it can also be used in large-scale analyses ${ }^{5}$.

\section{Juraj Gregan}

The Research Institute of Molecular Pathology (IMP), Dr. Bohr-Gasse 7, Vienna, A-1030, Austria e-mail:gregan@imp.univie.ac.at

1. Dohmen, R.J., Wu, P. \& Varshavsky, A. Science 263 1273-1276 (1994)

2. Labib, K., Tercero, J.A. \& Diffley, J.F. Science $\mathbf{2 8 8}$ 1643-1647 (2000).

3. Lindner, K. et al. Mol. Biol. Cell 13, 435-444 (2002).

4. Gregan, J. et al. Mol. Biol. Cell 14, 3876-3887 (2003)

5. Kanemaki, M. et al. Nature 423, 720-724 (2003).

\section{Biotech in post-TRIPS India}

\section{To the editor:}

The Indian government's substantial investment in patent infrastructure, together with recent modifications to Indian patent laws, reflects the country's commitment, both in letter and spirit, to adhering to the principles laid down by the World Trade Organization's (WTO, Geneva) agreement on Trade-Related Aspects of Intellectual Property Rights (TRIPS). For India's biotech sector, however, a stronger patent system is unlikely to be sufficient to spark a boom of innovation. Indian companies simply cannot compete with the financial resources at the disposal of their Western counterparts. TRIPS implementation essentially signals the initiation of a race that is unfair.

TRIPS defines the minimum standards of the system of intellectual property (IP) rights that is to be enforced by the WTO in its 147 member states. Among the most important part of TRIPS is article 27, which calls for a uniform product patent regime in all manufacturing sectors and in all member countries. TRIPS is equivalent to a new law that commits India to cease the reengineering or independent development of products patented elsewhere.

From 1970 onwards, Indian IP law changed from granting product patents to recognizing only process patents. This change was critical in facilitating the development of an Indian generic pharmaceutical industry and the emergence of an Indian public health care system that could cater to the poorer sections of society. With the implementation of TRIPS, however, India has been forced to modify its patent law of 1970; two amendments have already been made by parliament and currently a third amendment is under review. As well as process patents, the changes now allow the patenting of products including biopharmaceutical and pharmaceutical formulations, compositions, combinations, novel dosage forms and herbal extracts. What cannot be patented are new uses or properties of substances, intermediates used in the manufacture of drugs, traditional knowledge, knowledge in the public domain, business practices, medical practices and discoveries of living and non-living substances occurring in nature. Finally, there are a few loose ends, such as drug delivery systems, parts of microorganisms, functioning DNA sequences and parts of DNA sequences, whose patentability is not very clear.

To be more efficient and responsive in a post-TRIPS world, the Indian government has also upgraded its patent offices. Interviews carried out with officials at the patent offices in Mumbai and Chennai reveal that in the past 2 to 4 years, there has been substantial investment in patent office infrastructure in major cities, including the computerization of records, the establishment of libraries and the implementation of patent tracking systems. The number of employees in these offices has also increased tremendously. For instance, in Mumbai there were 7 employees in 1998-1999; today, there are 70, and more are expected. The time to process an Indian patent has been reduced from 5-7 years to 2 years on average.

By insisting on a move to product patents from process patents for all manufactured products, TRIPS shifts the compensation for innovation creation from secondary innovators to primary innovators. In an ideal world, this would motivate Indian firms to invest in the creation of innovations and become primary innovators. Conversely, they would be less inclined to invest in the independent development (or reengineering) and marketing of innovations already protected by preexisting foreign patents.

There are several reasons, however, why the situation is somewhat more complex. According to a recent report ${ }^{1}$, the Indian pharmaceutical industry comprises about 23,000 manufacturing units. It is common knowledge that among these thousands of firms, at most only a hundred have the financial and technological wherewithal to undertake research and development (R\&D) activities that can produce radical innovations. Furthermore, even these hundred or so elite Indian firms are dwarfed by Western multinationals in terms of financial resources for R\&D investment. As external sources of finance, such as venture capital markets, remain rather sluggish, it is difficult to see how Indian companies can compete with Western counterparts as primary innovators. They simply do not have enough resources to invest in $\mathrm{R} \& \mathrm{D}$.

At the same time, having stronger IP rights is not automatically going to induce foreign firms to increase their investment in India or their collaborations with Indian firms. For this to happen, several other necessary conditions for conducting business transactions need to be satisfied. These include a good 'business climate,' easy access to dependable infrastructure and the ability to conduct business transactions transparently and efficiently. In India (and many other developing countries), the main problems with conducting business 